Article

\title{
Cellular Telephones and Natural Disaster Vulnerability
}

\author{
Hideki Toya ${ }^{1}$ and Mark Skidmore ${ }^{2, *}$ \\ 1 Faculty of Economics, Nagoya City University, Mizuho-cho, Mizuho-ku, Nagoya 467-8501, Japan; \\ toya@econ.nagoya-cu.ac.jp \\ 2 Department of Agricultural, Food, and Resource Economics, Michigan State University, East Lansing, \\ MI 48824-1039, USA \\ * Correspondence: mskidmor@msu.edu; Tel.: +1-517-353-9172
}

Received: 21 June 2018; Accepted: 10 August 2018; Published: 21 August 2018

check for updates

\begin{abstract}
A global revolution in information and communication technologies (ICT) has occurred over the past few decades, emerging first in industrialized countries and then in developing countries. While researchers have examined many facets of the ICT revolution, relatively little work has systematically examined the degree to which ICT has reduced natural disaster vulnerability. In this article we use cross-country data over the 1980-2013 period to estimate the relationship between newly-emerging cell phone access/use and disaster-induced fatalities. Our estimates suggest that a one-standard-deviation increase in cell phone usage reduces disaster fatalities by nearly one half. The estimated effect increases to almost three quarters for geologic events where people are typically afflicted without warning. The largest marginal benefit from cell phones in terms of saving lives come from events where there is typically no warning, thus, many are caught by surprise; cell phones are used to call for help and coordinate assistance.
\end{abstract}

Keywords: economic development; natural disasters; information/communication technology; cell phone

\section{Introduction}

The consensus among a majority of climate scientists is that we should expect an increase in both the number and severity of climatic events. It is, therefore, important that societies consider a full range of measures to protect and sustain life-use of technology is one important factor. In recent decades societies have been transformed by the information/communication technological (ICT) revolution. Emerging technology has made communications and information more accessible than in any period in history. While the ICT revolution blossomed in the industrialized world, the most dramatic impacts have been experienced in developing countries, enabling the expansion of vast communications networks without traditional cable infrastructures. In this article, we examine the degree to which changes in ICT have resulted in fewer lives lost when natural disasters strike.

As a country develops it reduces vulnerability to natural disasters by devoting greater resources to safety; economic development enables significant improvements in ICT and in the quality of housing infrastructure and the like. Increased income also enables economic agents to devote more resources to safety. Anbarci, Escaleras and Register [1], Kahn [2], Toya and Skidmore [3], and Kellenberg and Mobarak [4] demonstrated how economic development reduces vulnerability to natural disasters. Most recently, Toya and Skidmore [5] presented new evidence that emerging ICT has played an important role in reducing disaster-related fatalities. The present study builds on the Toya and Skidmore [5] analysis by offering a more detailed evaluation of the underlying socio-economic circumstances that enable improved communications to reduce disaster-induced fatalities. We also 
examined the role that cellular telephones phones (cell phones) play in reducing fatalities for various types of disasters. Cell phones can help to reduce fatalities via two routes: First, they facilitate the dissemination of warning information that helps people to take protective measures during crises. Second, they facilitate the coordination of recovery efforts in the midst and aftermath of disaster events. While a number of case studies offer evaluations of ICT's use in previous disaster situations, to our knowledge Toya and Skidmore [5], and the present article, are the first to systematically evaluate the role of ICT in preserving life during and immediately following natural disasters.

Our analysis is based on a general framework and pattern in which increasing wealth and access to resources, including ICT, enable individuals and societies to take precautionary measure against potential risks. In the more specific case of natural disasters, greater resources and access to ICT can help to save lives. To conduct our analysis, we collected and merged cell phone use, economic and geographic data with information on total deaths caused by natural disasters in 120 countries for the years 1980 to 2013, inclusive. Information on disasters is available from the Office of U.S. Foreign Disaster Assistance/Center for Research on the Epidemiology of Disasters (OFDA/CRED). Data on disasters include disaster location and type, disaster losses in terms of fatalities, number of people affected, and economic losses. In some cases, disaster magnitudes as measured by wind speeds, size of land area flooded, and Richter scale readings. We used these data to estimate the relationship between mobile cell phone usage and natural disaster-induced fatalities, while controlling for a range of other factors found to be important determinants of disaster-induced fatalities. We also explored the degree to which the level of economic development enables cell phones to be used during disaster crises. For example, without the presence of emergency personnel to assist those in need, cell phones may not be effective in reducing fatalities in the midst of a disaster event. Similarly, early warnings facilitated by cell phones are more effective in the presence of transportation and other critical infrastructure so that economic agents are able to move out of harm's way quickly.

In the following section, we provide a review of the relevant literature on the role of ICT in reducing disaster vulnerability and, more generally, the role of economic development in disaster impact mitigation. In Sections 3 and 4, we present the empirical framework and analysis, respectively. Section 5 concludes.

\section{Literature Review and Theoretical Discussion}

We divide our review of the literature into two parts: The research on ICT and disaster vulnerability, and the role of economic development in reducing disaster-induced fatalities.

\subsection{Information and Communication Technologies}

A large body of research has examined the emergence of cell phones in the developing world as well as their impact on various aspects of economic activity. For example, researchers have examined the use of cell phones in developing countries to assist farmers' marketing decisions (Tadesse and Bahiigwa [6]; Muto and Yamano [7]), mobile banking (Donner and Tellez [8]), and the adoption of agricultural technology (Kiiza and Pederson [9]). Donner [10] provides a comprehensive literature review of 231 studies of cell phone use in the developing world, but none of these studies considered cell phone use in the context of natural disasters. There is, however, also a body of work on the role of what we refer to as "old technology", which includes the use of sirens, radio communications, and the like to disseminate warnings and disaster information. In industrialized countries, where landline telephone communications have been in place for decades, local authorities have put in place emergency calls through "reverse 911" dispatch technologies. However, the emergence of cell phone and Internet communications over the last two decades presents new potential for sharing disaster warning information, as well as communicating in the aftermath of disasters. While cell phones and the Internet on their own can enable communication prior to and during crises, effectiveness is enhanced when authorities develop systems to communicate warnings that are integrated with ICT. In this regard, there is an emerging body of case study research that considers the role of ICT 
in disaster mitigation. Samarajiva and Waidyanatha [11] evaluated mobile phone technologies in Sri Lanka, concluding "mobile phones as the reliable, effective, and affordable solutions for alerting last-mile communities. Disaster risk reduction can be improved using mobile application and leverage the explosive diffusion of the technology even among the poor in developing countries" (page 58). Jagtman [12] also evaluated the challenges and opportunities of using cell phones as part of early warning systems in the Netherlands. Some of the challenges she highlighted include the proper identification of those who truly need to be warned, use of appropriate messaging language, and the risks of unauthorized information being messaged. The recent work of Wang, et al. [13] examined the use of social media in emergency response in China during the 2012 Beijing rainstorm. Another article by Khalafzai and Nirupama [14] considered the ways in which Pakistani women are empowered by ICT, thus, improving disaster resilience. Within an industrialized country context, Vieweg, et al. [15] highlighted the use of microblogging from social media tools such as Twitter to improve situational awareness during disasters. However, not all researchers have concluded that the use of cell phones is the most cost-effective means of dissemination disaster warning information. For example, Collin and Kapucu [16] reviewed the literature on tornado warning mechanisms and concluded that local government use of weather radio warning systems is the most cost-effective means of sharing tornado warning information. Quarentelli [17] offered an assessment of potential problems of the ICT revolution for disaster planning and management. Of greatest relevance is the concern about ICT system failures, which can generate enormous costs for society. Importantly, overreliance on ICT in disaster management poses risks because disaster events can lead to short-term and longer-term communications outages.

Most closely related to the present work is the recently published article by Toya and Skidmore [5]. Using data on natural disaster fatalities from many countries over the 1980-2013 period, they found a strong negative relationship between the emergence of ICT and disaster-induced fatalities. They also concluded that cell phones, as opposed to Internet access, is the dominant technology that helped to save lives during crises. Further, they showed that the presence of a stronger human capital base enhanced the role ICT plays in reducing fatalities. The present work expands on this analysis by offering a more detailed discussion and examination, focusing attention on the role of cell phones in reducing fatalities for various types of disasters in developing and industrialized countries. Specifically, Toya and Skidmore [5] only considered a single aggregate disaster variable, whereas in the present study we consider geologic and climatic disasters, as well as specific disaster types such as earthquakes, volcanoes, mass movements, floods, and storms. Toya and Skidmore [5] emphasized the role of human capital, where the present study focuses on key interactions between cell phone availability and the level of development. We also examine the robustness of the empirical results using techniques to address both serial correlation of error and spatial correlation.

\subsection{Economics of Natural Disasters}

Any economy's response to disaster events is dependent on its level of development. Wildavsky [18] and Horwich [19] argued that increased income translates to a general increase in the level of safety, where the degree of safety is a natural outcome of a growing market economy. Wildavsky [18] defined safety as protection against hazardous circumstances (e.g., less dangerous machinery, improved construction quality, increased reliability of automobile braking and steering mechanisms, and more reliable means of transportation and communication). Since the demand for safety tends to rise with income, a nation's per capita income is a good initial indication of its degree of vulnerability. Increases in income not only lead to improvements in general safety, but also to additional protection against natural disasters. In the context of natural disasters, Kahn [2] and Toya and Skidmore [3] showed that fatalities are reduced as income rises. As a society becomes more developed, it tends to implement policies designed to reduce risks, focusing first on the most hazardous factors in the environment. 
Tol and Leek [20] and Burton et al. [21] also discussed the potential for reduced vulnerability as income increases. Burton et al. [21] presented some evidence of an inverse relationship between deaths due to natural disasters and income in twenty countries for the years 1973 and 1986. Tol and Leek [20] suggested that there is a transition between the relatively vulnerable and invulnerable that occurs somewhere in the modernization process. While disasters result in fatalities in both industrialized and developing countries, Albala-Bertrand [22] made the case that the people most affected by direct disaster events are primarily those with weak economic and political bases. As a general confirmation of this view, Alexander [23] showed that 95 percent of the deaths occur in the developing world.

Using disaster data from OFDA/CRED, Kahn (2005) showed that income and institutional quality are important determinants of human casualties from natural disasters. Of special note, Kahn (2005) demonstrated that while the probability of disaster occurrence is not related to the level of development, the number of deaths, injured, and homeless are reduced as income rises. He also provided evidence that more democratic countries experience fewer human losses than do less democratic countries. Using data similar to that of Kahn [2], Anbarci et al. [1] examined the relationship between earthquake fatalities and income inequality, finding that countries with greater inequality experience greater losses. Toya and Skidmore [3] extended this research by examining other economic factors such as human capital and the degree of trade openness, and found that both greater human capital and openness tend to reduce losses from natural disasters. However, Kellenberg and Mobarak [4] demonstrated that there may be important nonlinearities between the level of development and disaster impacts. Other research such as Briguglio [24], Adger [25] and Pelling and Uitto [26] examined aspects of social and economic vulnerability to disasters and climate change more generally.

In recent decades the world has experienced, as part of its development, the advancement of new information and communication technologies. With the exception of the aforementioned work of Toya and Skidmore [5], little systematic research has been conducted to evaluate the role of ICT in reducing fatalities. The present work extends both the literatures on ICT and the economics of disasters by offering an empirical evaluation of the degree to which the emergence of cell phones has reduced disaster-induced fatalities. Generally, we hypothesized that mobile cell phones help to preserve life in two ways: First, cell phones serve as an effective conduit for dissemination warning information when disasters strike. Second, cell phones can be used to coordinate recovery activities in the aftermath of disasters. While we were not able to directly distinguish between these two effects, we do present an indirect test. Existing weather forecasting technology enables effective lead times in disseminating warnings for storms, floods, and the like. Although cell phones can be used to share storm warnings, as discussed in the literature review, pre-existing technologies have been used to effectively disseminate information. However, there is no similar forecasting for geologic events such as earthquakes. Thus, many are unprepared for such events, and this is where cell phones can be of greatest benefit. Our examination included an evaluation of major disaster types to test the effectiveness of cell phones in various disaster contexts. For the reasons described above, we hypothesized that cell phones will be more effective in terms of reducing disaster-related fatalities for geologic disasters relative to climatic disasters. We now turn our attention to the empirical analysis.

\section{Methodology}

\subsection{Data}

Natural disaster data used in this analysis come from the OFDA/CRED International Database (www.emdat.be) [27]. The OFDA/CRED database was developed as a result of collaboration between the Office of U.S. Foreign Disaster Assistance and the Center for Research on the Epidemiology of Disasters. Establishing better preparedness for disasters, and improving their prevention have been primary concerns for donor agencies, implementing agencies, and affected countries. Thus, there is a need for quality information on disasters and their human impact, by country and type of disasters: The OFDA/CRED initiative has resulted in a validated database on disaster impacts. 
Economic data, which are available from several sources (Feenstra, et al. [28]; World Development Indicators [29]), were combined with disaster data. The unit of analysis is the disaster event, where we examined 3950 disasters in 120 countries over the 1980-2013 period. This dataset enabled us to conduct empirical analyses to determine the relationship between the emergence of cell phones and disaster-induced fatalities while controlling for a range of other factors.

OFDA/CRED uses a set of criteria to classify natural disasters (ten or more people killed, 100 or more people affected/injured/homeless, significant damages incurred, a declaration of a state of emergency, and/or an appeal for international assistance; see [30]). Although the OFDA/CRED provides information on a number of natural disaster types, we restricted our analysis to earthquakes, floods, slides (wet and dry), volcanic eruptions, and extreme winds. Hurricanes, tornadoes, typhoons, and other weather-related events are included in the extreme winds category. We omitted from this analysis the following disaster types: Drought, epidemics, extreme temperature, wildfire, and insect infestations. Our analysis focused on rapid onset disasters. OFDA/CRED systematically validates the contents of the database through citing and cross-referencing sources. While we would have liked to include disaster magnitude (wind speed, Richter scale reading, and flood area) in our core analysis as disaster magnitude is a very important determinant of disaster impact, such information is not available in every case. One potentially important econometric issue related to this particular data source warranted our attention; it is possible that the likelihood of a disaster event being recorded by OFDA/CRED depends, in part, on the level of development. Thus, bias could be introduced into the analysis. However, Kahn [2] demonstrated in a careful analysis that the probability of a disaster event occurring and being recorded is not dependent on the level of development. With the exception of flood impacts which were shown by Kahn to be marginally correlated with the level of development, high and low-income countries are equally likely to experience a disaster event that is recorded by OFDA/CRED. Some researchers have highlighted concerns about potential bias resulting from the selection criteria for the Emergency Events Database (EM-DAT) database. Felbermayr and Gröschl [31] have shown that EM-DAT tends to include larger disaster events and, thus, may result in biased estimates of natural disaster impacts on economic growth. We considered using the GAME disaster dataset developed by Felbermayr and Gröschl [31], which is based on primary geophysical and meteorological information. However, the database they compiled only includes fatality information on those disaster events that match up with the EM-DAT database. Since our evaluation examines disaster-induced fatalities, there is no advantage to using this other database because their fatality data come from EM-DAT. Regardless, Kahn's [2] analysis suggested potential bias in the context of disaster-related fatalities is not a major concern. Further, the GAME monthly event level dataset contains numerous cases in which there is more than one disaster within a country in a given month. Thus, one cannot disaggregate fatalities associated with each event. Finally, GAME data include disaster information for the years 1979 to 2010, whereas our data were for 1980 to 2013. ICT is changing so rapidly that the three later years are important. Relying on Kahn's result, we moved directly to an analysis of the determinants of disaster-related fatalities.

Summary statistics, data sources, and a list of countries included in the analyses are presented in Table 1 and the Appendix A Tables A1 and A2.

For all disaster events recorded in the OFDA/CRED database over the 1980-2013 period, on average 4.5 percent of all those affected by a disaster were fatalities. In our sample, the most common types of disasters were floods and extreme wind, accounting for 50 and 32 percent of the total number of disaster events, respectively. Six percent of the total resulted from slides, 11 percent from earthquakes, and volcanic eruptions accounted for less than one percent of the total.

Our key independent variable is mobile cell phone use; specifically, we use the number of cell phone subscriptions per 100 people. It is important to note that over the time period of examination, cell phone use went from virtually zero everywhere to near full saturation across a broad set of countries. As shown in Figure 1, cell phone usage occurred in waves, beginning in the early 1990s in developed countries, with developing countries following about a decade later. To rigorously 
evaluate the impact of cell phones on mitigating disaster fatalities, we controlled for other factors found to be important in previous studies (Kahn [2]; Anbarci, et al. [1]; Toya and Skidmore [3]; Kellenberg and Mobarak [4], such as landline phone access, income, human capital, trade openness, and size of government. We examined these issues by including in our regression analysis per capita GDP, human capital index per person based on average years of schooling and returns to education, degree of openness ((merchandise exports + merchandise imports)/GDP), and government size (government consumption/GDP). We also controlled for the proportion of households with landline phone access, as well as year dummy variables. Based on the previous literature and corresponding discussion, we expected higher levels of GDP per capita, share of government consumption, trade openness, and human capital to reduce death tolls, and landline phone access to reduce natural disaster-induced fatalities.

Table 1. Summary of Statistics of Variables.

\begin{tabular}{lccc}
\hline & Mean & Standard Deviation & Number of Observations \\
\hline Number of fatalities/(Number of fatalities + & 0.045 & 0.142 & 3950 \\
Number of affected people) & 2.220 & 1.829 & 3950 \\
$\log (1+$ Cell $)$ & 2.105 & 1.248 & 3950 \\
$\log (1+$ Phone $)$ & 8.442 & 1.106 & 3950 \\
$\log ($ GDP per capita $)$ & -1.855 & 0.409 & 3950 \\
$\log ($ Government consumption $)$ & -1.333 & 0.747 & 3950 \\
$\log ($ Openness $)$ & 0.821 & 0.249 & 3950 \\
$\log ($ Human capital $)$ & 0.215 & 0.853 & 3950 \\
$\log (1+$ Cell $) \times$ Geologic disasters & 2.005 & 1.865 & 3950 \\
$\log (1+$ Cell $) \times$ Climatic disasters & 0.201 & 0.824 & 3950 \\
$\log (1+$ Cell $) \times$ Earthquake & 0.009 & 0.183 & 3950 \\
$\log (1+$ Cell $) \times$ Volcano Eruption & 0.005 & 0.144 & 3950 \\
$\log (1+$ Cell $) \times$ Mass Movement Dry & 1.173 & 1.744 & 3950 \\
$\log (1+$ Cell $) \times$ Flood & 0.710 & 1.469 & 3950 \\
$\log (1+$ Cell $) \times$ Storm & 0.122 & 0.637 & 3950 \\
$\log (1+$ Cell $) \times$ Mass Movement Wet & 1.385 & 1.834 & 3950 \\
$\log (1+$ Cell $) \times$ High income & 0.835 & 1.515 & 3950 \\
$\log (1+$ Cell $) \times$ Low income & 0.558 & 1.388 & 3950 \\
$\log (1+$ Cell $) \times$ High Income_OECD & 0.081 & 0.545 & 3950 \\
$\log (1+$ Cell $) \times$ High Income_non OECD & 1.478 & 3950 \\
$\log (1+$ Cell $) \times$ Upper Middle Income & 0.746 & 1.459 & 3950 \\
$\log (1+$ Cell $) \times$ Lower Middle Income & 0.726 & 0.569 & \\
$\log (1+$ Cell $) \times$ Low Income & 0.110 & & \\
\hline
\end{tabular}

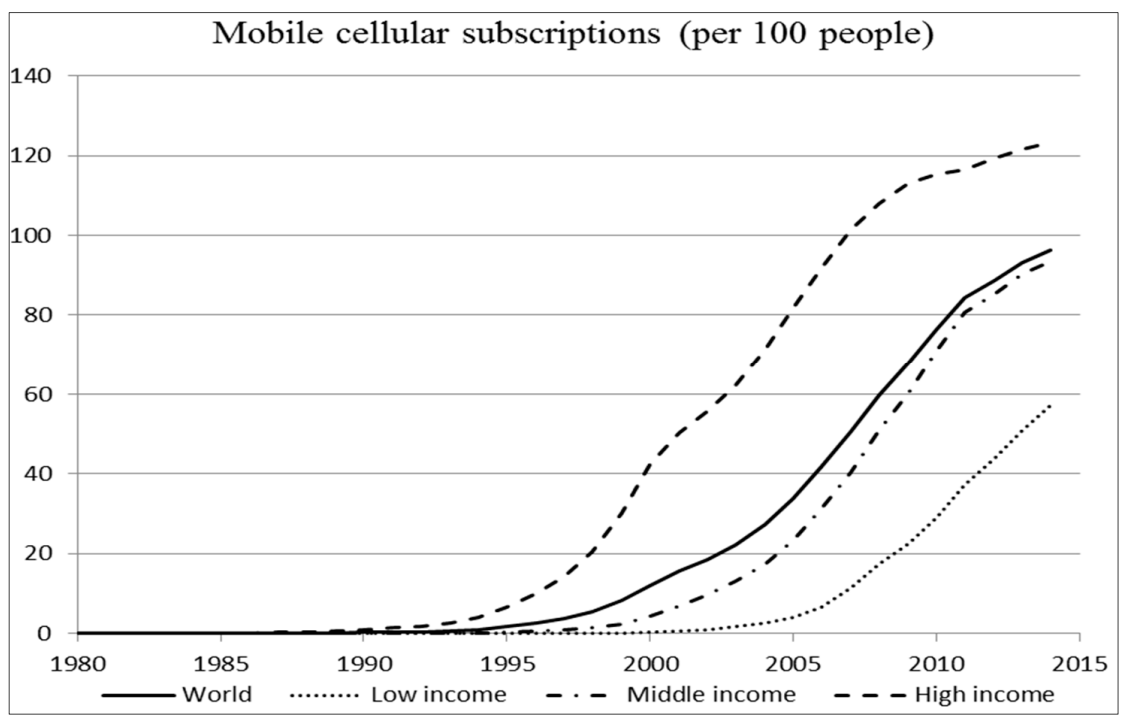

Figure 1. Patterns of Cell Phone Usage over Time. Source: World Development Indicators [29]. 


\subsection{Method of Analysis}

We estimated a series of regressions using detailed disaster event data for many countries over the 1980-2013 period to determine the relationship between disaster-induced fatalities and cell phone access. Given the cross-sectional time series aspects of our data, we used panel data econometric techniques. Our basic regression is characterized by Equation (1):

$$
\left(\text { fatalities }_{i j t}\right) /\left(\text { fatalities }_{i j t}+\text { affected }_{i j t}\right)=\beta_{m}\left(\text { cell }_{i t}\right)+\beta_{n}\left(y_{k i t}\right)+\alpha_{i}+d_{j}+t_{t}+e_{i j t}
$$

where fatalities $s_{i j t}$ is the total number of deaths caused by natural disaster $j$ in country $i$ during year $t$, affected ${ }_{i j t}$ is the number of people affected by the event but not killed, cell $_{i t}$ is defined as $\ln (1$ plus the number of cell phone subscriptions per 100 people), and $y_{k i t}$ represents a vector of $k$ variables as previously discussed, that may determine the ratio of deaths per number of people affected by a natural disaster, $d$ is a set of dummy variables signifying the type of disaster, $\alpha$ is a vector of fixed effects for country $i$, and $t$ represents a series of year dummy variables. Regressions were estimated using a technique where the standard errors are clustered at the country level to address temporal autocorrelation and heteroscedasticity. Clustered-standard errors perform well when the number of clusters is reasonably large (Bertrand et al. [32]; Kezdi [33]). The dependent variable is the ratio of fatalities to the total number of people affected by the disaster plus fatalities; use of this ratio enabled us to examine the role that mobile cell phone access/use plays in reducing fatalities, relative to the total number of people affected by the disaster. If we use fatalities or fatalities as a proportion of the population as the dependent variable (as is the case with many other studies), results are qualitatively similar to those presented in this article. Use of fatalities as a proportion the total number of people affected allowed us to assess the role of cell phones in reducing fatalities more effectively; cell phones tend not reduce the numbers affected but can help to save lives. However, we also note that the potential impacts of control variables such as per capita GDP are likely to be muted in this specification, because increases in GDP per capita may reduce lives lost as well as the total number of affected people.

\section{Results and Discussion}

Table 2 presents a series of regressions using data for all natural disasters recorded for all countries in our data set over the 1980-2013 period. In column 1, we present a base regression in which only our measure of cell phone use is included, along with a baseline set of control variables. In column 2, we add additional explanatory variables (landline phone access, GDP per capita, government consumption, trade openness, and human capital). Columns 3 and 4 repeat columns 1 and 2 except the cell phone variable is interacted with geologic and climatic disaster dummy variables. This specification allowed us to examine the role of cell phones in saving lives, depending on the nature of the disaster. Finally, columns 5 and 6 present estimates where the cell phone variable is interacted with a set of disaster type dummy variables (earthquake, volcano, dry mass movement, flood, storm, and wet mass movement). The column 5 and 6 estimates offer a more detailed assessment of how cell phones help to save lives in various types of disaster events. This additional analysis may offer insight into how cell phones may be used during disaster events. For example, an earthquake may offer no lead time preparation, so for this type of disaster cell phones would be used only in coordinating response and relief efforts. However, in the case of climatic disasters, weather forecasting in combination with media and communication systems warn of expected weather events. Thus, more people are able to take precautionary measures. If this is the case, then we might expect a relatively larger impact of cell phones in cases of geologic events. Our analysis will shed light on this issue. 
Table 2. Cell phones and natural disaster fatalities (1980-2013).

\begin{tabular}{|c|c|c|c|c|c|c|}
\hline $\log (1+$ Cell $)$ & $\begin{array}{l}-0.012 * * \\
(-2.372)\end{array}$ & $\begin{array}{l}-0.012^{* *} \\
(-2.353)\end{array}$ & & & & \\
\hline $\log (1+$ Cell $) \times$ Geologic Disasters & & & $\begin{array}{l}-0.018^{* * *} \\
(-2.721)\end{array}$ & $\begin{array}{l}-0.018^{* * *} \\
(-2.694)\end{array}$ & & \\
\hline $\log (1+$ Cell $) \times$ Climatic Disasters & & & $\begin{array}{l}-0.011^{* *} \\
(-2.294)\end{array}$ & $\begin{array}{l}-0.012 * * \\
(-2.287)\end{array}$ & & \\
\hline $\log (1+$ Cell $) \times$ Earthquake & & & & & $\begin{array}{l}-0.019^{* * *} \\
(-3.108)\end{array}$ & $\begin{array}{l}-0.019^{* * *} \\
(-3.030)\end{array}$ \\
\hline $\log (1+$ Cell $) \times$ Volcano Eruption & & & & & $\begin{array}{l}-0.029 \\
(-1.561)\end{array}$ & $\begin{array}{l}-0.029 \\
(-1.568)\end{array}$ \\
\hline $\log (1+$ Cell $) \times$ Mass Movement Dry & & & & & $\begin{array}{c}0.022 \\
(0.553)\end{array}$ & $\begin{array}{c}0.021 \\
(0.534)\end{array}$ \\
\hline $\log (1+$ Cell $) \times$ Flood & & & & & $\begin{array}{l}-0.014^{* * *} \\
(-2.642)\end{array}$ & $\begin{array}{l}-0.015^{* * *} \\
(-2.621)\end{array}$ \\
\hline $\log (1+$ Cell $) \times$ Storm & & & & & $\begin{array}{l}-0.011 * * \\
(-2.577)\end{array}$ & $\begin{array}{l}-0.011 * * \\
(-2.488)\end{array}$ \\
\hline $\log (1+$ Cell $) \times$ Mass Movement Wet & & & & & $\begin{array}{c}0.011 \\
(1.183)\end{array}$ & $\begin{array}{c}0.011 \\
(1.130)\end{array}$ \\
\hline $\log (1+$ Phone $)$ & & $\begin{array}{l}-0.001 \\
(-0.142)\end{array}$ & & $\begin{array}{c}0.000 \\
(-0.020)\end{array}$ & & $\begin{array}{l}-0.001 \\
(-0.194)\end{array}$ \\
\hline $\log$ (GDP per capita) & & $\begin{array}{c}0.012 \\
(0.646)\end{array}$ & & $\begin{array}{c}0.011 \\
(0.626)\end{array}$ & & $\begin{array}{c}0.013 \\
(0.678)\end{array}$ \\
\hline $\log$ (Government Consumption) & & $\begin{array}{l}-0.005 \\
(-0.447)\end{array}$ & & $\begin{array}{l}-0.004 \\
(-0.378)\end{array}$ & & $\begin{array}{l}-0.003 \\
(-0.254)\end{array}$ \\
\hline $\log$ (Openness) & & $\begin{array}{c}0.002 \\
(0.191)\end{array}$ & & $\begin{array}{c}0.001 \\
(0.145)\end{array}$ & & $\begin{array}{c}0.001 \\
(0.143)\end{array}$ \\
\hline $\log$ (Human Capital) & & $\begin{array}{c}0.031 \\
(0.392)\end{array}$ & & $\begin{array}{c}0.034 \\
(0.428)\end{array}$ & & $\begin{array}{c}0.041 \\
(0.525)\end{array}$ \\
\hline Number of Countries & 120 & 120 & 120 & 120 & 120 & 120 \\
\hline Number of Observations & 3950 & 3950 & 3950 & 3950 & 3950 & 3950 \\
\hline R-square: Within & 0.146 & 0.146 & 0.146 & 0.147 & 0.153 & 0.153 \\
\hline
\end{tabular}

Note first that none of the control variables are statistically significant, which is partly due to the nature of the dependent variable; increases in variables such as per capita GDP tend to reduce lives lost as well as numbers affected, so these variables tend to be insignificant determinants of the ratio of fatalities to people affected. In contrast, if cell phones have any effect it will be on fatalities and not on the numbers affected. Exploratory estimates not presented here show that cell phones do have a negative effect on fatalities, but not a statistically significant effect on numbers affected. In addition, the fixed effects estimator uses the within country variation to generate the parameter estimates, so that coefficients on variables which do not change much over time are less likely to be statistically significant. For example, landline access changed little in countries over time; thus, there is little variation in this variable within the fixed effects framework. Thus, it would be unsurprising to see that the coefficient on these variables was statistically insignificant.

The coefficients on the cell phone variables are all negative and statistically significant in columns 1-4. We, therefore, focus our discussion on the estimates with the broadest set of variables included in the specifications. To understand the magnitude of the impact of cell phones in terms of saving lives, consider the column 2 estimate. Suppose cell phone subscriptions per 100 people in a country increased from the average ( 8.50 per 100 ) by one standard deviation $(52.25$ per 100$)$, which is a 
614 percent increase in usage. This increase is estimated to reduce the ratio of fatalities to those affected by 47 percent. That is, cell phone access/use reduces disaster-induced fatalities by nearly 50 percent. From column 4, cell phones are more effective in saving lives during geologic than climatic events. The coefficient estimate on the cell phone-geologic disaster interaction variable suggests that cell phones reduce fatalities by 69 percent. This result suggests that the largest marginal benefit from cell phones in terms of saving lives is with geologic events, in which there is typically no warning; many are caught by surprise and, thus, use cell phones to call for help and coordinate assistance. This result is confirmed in column 6 where the largest cell phone effect is found with earthquakes and volcanoes.

In Table 3, we present a set of regressions to determine whether the level of development influences the degree to which cell phones reduce disaster fatalities. Columns 1 and 2 of Table 3 mirror columns 1 and 2 of Table 2, except the cell phone variable is interacted with high and low income dummy variables (as well as high, medium-high, medium-low, and low income), as defined in World Development Indicators [29]. These estimates show that cell phone expansion saves more lives in high income than in low income countries. Low income countries have fewer disaster response capabilities, so this result is in line with expectations. Columns 3 and 4 of Table 3 confirm this result by showing that cell phones reduce fatalities more in high and middle income countries relative to low income countries.

Table 3. Cell phones and natural disaster fatalities by level of development (1980-2013).

\begin{tabular}{|c|c|c|c|c|}
\hline $\log (1+$ Cell $) \times$ High income countries & $\begin{array}{c}-0.013^{* * *} \\
(-2.643)\end{array}$ & $\begin{array}{c}-0.014^{* * *} \\
(-2.693)\end{array}$ & & \\
\hline $\log (1+$ Cell $) \times$ Low income countries & $\begin{array}{l}-0.010 * \\
(-1.741)\end{array}$ & $\begin{array}{l}-0.010 * \\
(-1.800)\end{array}$ & & \\
\hline $\log (1+$ Cell $) \times$ High income OECD & & & $\begin{array}{l}-0.012 * * \\
(-2.576)\end{array}$ & $\begin{array}{l}-0.013^{* *} \\
(-2.242)\end{array}$ \\
\hline $\log (1+$ Cell $) \times$ High income non OECD & & & $\begin{array}{l}-0.014 * * \\
(-2.230)\end{array}$ & $\begin{array}{l}-0.015^{* *} \\
(-2.169)\end{array}$ \\
\hline $\log (1+$ Cell $) \times$ Upper middle income & & & $\begin{array}{l}-0.013 * * \\
(-2.326)\end{array}$ & $\begin{array}{l}-0.015^{* *} \\
(-2.578)\end{array}$ \\
\hline $\log (1+$ Cell $) \times$ Lower middle income & & & $\begin{array}{l}-0.010 * \\
(-1.745)\end{array}$ & $\begin{array}{l}-0.010 * \\
(-1.864)\end{array}$ \\
\hline $\log (1+$ Cell $) \times$ Low income & & & $\begin{array}{c}-0.009 \\
(-1.054)\end{array}$ & $\begin{array}{c}-0.009 \\
(-1.065)\end{array}$ \\
\hline $\log (1+$ Phone $)$ & & $\begin{array}{c}-0.003 \\
(-0.477)\end{array}$ & & $\begin{array}{c}-0.002 \\
(-0.236)\end{array}$ \\
\hline $\log$ (GDP per capita) & & $\begin{array}{c}0.019 \\
(1.034)\end{array}$ & & $\begin{array}{c}0.018 \\
(0.949)\end{array}$ \\
\hline $\log$ (Government Consumption) & & $\begin{array}{c}-0.001 \\
(-0.072)\end{array}$ & & $\begin{array}{c}-0.001 \\
(-0.138)\end{array}$ \\
\hline $\log$ (Openness) & & $\begin{array}{c}0.002 \\
(0.173)\end{array}$ & & $\begin{array}{c}0.002 \\
(0.230)\end{array}$ \\
\hline $\log$ (Human Capital) & & $\begin{array}{c}0.022 \\
(0.294)\end{array}$ & & $\begin{array}{c}0.032 \\
(0.431)\end{array}$ \\
\hline $\begin{array}{l}\text { Number of Countries } \\
\text { Number of Observations } \\
\text { R-square: Within }\end{array}$ & $\begin{array}{c}120 \\
3950 \\
0.146\end{array}$ & $\begin{array}{c}120 \\
3950 \\
0.146\end{array}$ & $\begin{array}{c}120 \\
3950 \\
0.146\end{array}$ & $\begin{array}{c}120 \\
3950 \\
0.147\end{array}$ \\
\hline
\end{tabular}

Notes: Numbers in parentheses are $t$-values correcting auto correlation and heteroscedasticity. ${ }^{* * *} p<0.01,{ }^{* *} p<0.05$, ${ }^{*} p<0.1$. Other independent variables included in regressions but not reported here are Constant, Earthquake, Flood, Mass Movement Wet, Mass Movement Dry, and Wind dummy variables; country dummy variables; and year dummy variables. Dependent variable: Number of fatalities/(Number of fatalities + Number of affected people). 
For robustness, we also considered potential spatial correlation in our data. That is since some disasters affect multiple countries, the dependent variable may be correlated across space. We addressed this issue by using a spatial lag model, which accounts for spatial dependence by including the serially correlated autoregressive term of the dependent variable as a regressor, as described in Anselin and Bera [34]. To generate the spatially dependent fatality variable, we first generated a distance-based weight matrix and a spatial lag variable using a new Stata procedure described in Kondo (2015) [35], where the threshold distance is set at $1000 \mathrm{~km}$. We explored various alternative distances with similar results. Countries located within this distance were considered to be within the region and those countries beyond $1000 \mathrm{~km}$ were considered to be outside the region. The weighting matrix was used to generate the spatial lag variable. We then included the spatial lag variable in our panel regression analysis. These regression results were nearly identical to those presented in this article, and are, therefore, not presented. (However, these estimates are available from the authors upon request.) We also estimated a set of regressions similar to those presented here except that the dependent variable is the number of fatalities. These regressions are also qualitatively similar to those presented in this article and, thus, not presented. Overall, our fixed effects estimates are very robust. However, we acknowledge the possibility that other factors such as improved emergency planning, increased information on hazards, improved search and rescue, and improved community responses are to some degree correlated with the emergence of ICT over the last several decades and, thus, partly explain the estimated life-saving effect attributed to cell phones. However, there is little evidence to suggest that these factors changed in the same dramatic fashion as cell phones as shown in Figure 1. Thus, these factors are not highly correlated with cell phone use are, thus, unlikely to bias the estimated coefficient on cell phones.

\section{Conclusions}

In this article, we examined the degree to which the emergence of cell phones has helped to reduce natural disaster-induced fatalities. While there is some emerging case study work that evaluates the ways ICT can be used to reduce disaster vulnerability, there is little research that offers a systematic empirical evaluation. The present article adds to the knowledge base by offering a detailed examination of how increased cell phone use has helped to reduce disaster fatalities. Our analysis indicates that a one standard deviation increases in cell phone use reduced fatalities relative to the total number of people affected by 47 percent on average. The estimated effect increases to 69 percent for geologic events where people are typically afflicted without warning. The evaluation also suggests that cell phones are most effective in high income countries where infrastructure and emergency assistance to enable a response is more readily available.

Some implications for disaster management and government can be drawn from this analysis. First, our evaluation suggests that increasing ICT in isolation is not as effective in terms of saving lives as it can be in combination with other efforts. To illustrate, the analysis suggests that cell phones are not as effective in places where emergency management capabilities are more limited: Using a cell phone to call for help is not effective if there is no one available to provide assistance. Similarly, sometimes disasters can disable or destroy cell phone towers or other essential telecommunications infrastructure, or cell phone networks can be completely overwhelmed during a crisis. From a management perspective, it is vital for telecommunications companies to have their own emergency plans and resources available to bring cell phone systems back online in the event of a disaster. Further, caution is warranted in relying too heavily on a single mode of communications. It may also be helpful to provide educational materials to cell phone users to improve the effectiveness of how they use ICT during and immediately following disaster events.

In recent decades, the dramatic changes in ICT that have occurred worldwide are transforming society. Our research demonstrates that ICT is helping to reduce disaster vulnerability, at least in terms of the number of lives lost. In future research, it may be beneficial to dive more deeply into actual cell phone activity immediately before, during, and following a crisis to learn more about the ways in 
which cell phones have been used to preserve life. Such research may reveal new opportunities for using the technology more effectively in crisis situations.

Author Contributions: Each author made substantial contributions to the conception of the work, analysis, interpretation of data; and in writing the article.

Funding: This research was supported by Nomura Foundation.

Conflicts of Interest: The authors declare no conflict of interest.

\section{Appendix A}

Table A1. Definitions and Sources of Variables.

\begin{tabular}{clc}
\hline Variables & \multicolumn{1}{c}{ Definition } & Source \\
\hline Number of fatalities & The number of persons confirmed as dead and persons missing and & CRED \\
presumed dead & CRED \\
Number of affected people & Sum of injured, homeless, and affected people & WDI \\
Cell & Mobile cellular subscriptions (per 100 people) & WDI \\
Phone & Telephone lines (per 100 people) & PWT \\
GDP per capita & Real GDP per capita & PWT \\
Government consumption & Share of government consumption & PWT \\
Openness & (Merchandise exports + Merchandise imports)/GDP & PWT \\
Human capital & Index of human capital per person & CRED \\
Geologic disasters & Dummy for Earthquake, Volcano Eruption, and Dry Mass Movement & CRED \\
Climatic disasters & Dummy for Wind, Flood, and Wet Mass Movement & WDI \\
High income countries & Dummy for High income OECD, High income non OECD, and Upper & WDI \\
Low income countries & middle income & Dummy for Lower middle income and Low income \\
\hline Sources: Center for Research on the Epidemiology of Disasters (CRED): The Emergency Events Database: (EM-DAT) \\
Université catholique de Louvain (UCL) CRED, D. Guha-Sapir [27], Brussels, Belgium. PWT (Penn World Table): \\
Feenstra, Robert C, Robert Inklaar and Marcel P. Timmer. 2015. “The Next Generation of the Penn World Table.” [28]. \\
American Economic Review, 105(10): 3150-3182 [36]. WDI: World Development Indicators [29].
\end{tabular}

Table A2. List of Countries Included in the Study.

\begin{tabular}{cccc}
\hline & \multicolumn{2}{c}{ High Income Countries } & \\
\hline High income OECD (27) & & & \\
Australia & Austria & Belgium & Canada \\
Chile & Czech Republic & France & Germany \\
Greece & Hungary & Iceland & Ireland \\
Israel & Italy & Japan & Korea, Rep. \\
Netherlands & New Zealand & Norway & Poland \\
Portugal & Slovak Republic & Slovenia & Spain \\
Switzerland & United Kingdom & United States & \\
\hline High income non OECD & (11) & & \\
Argentina & Barbados & Cyprus & Hong Kong SAR, China \\
Kuwait & Lithuania & Russian Federation & Saudi Arabia \\
Trinidad and Tobago & Uruguay & Venezuela, RB & \\
\hline Upper middle income & $(32)$ & & \\
Albania & Belize & Botswana & Brazil \\
Bulgaria & China & Colombia & Costa Rica \\
Dominican Republic & Ecuador & Fiji & Gabon \\
Iran, Islamic Rep. & Iraq & Jamaica & Jordan \\
Kazakhstan & Malaysia & Maldives & Mauritius \\
Mexico & Mongolia & Namibia & Panama \\
Paraguay & Peru & Romania & Serbia \\
South Africa & Thailand & Tunisia & Turkey \\
\hline
\end{tabular}


Table A2. Cont.

\begin{tabular}{cccc}
\hline \multicolumn{2}{c}{ Low Income Countries } \\
\hline Lower middle income (32) & Bangladesh & Bolivia & \\
Armenia & Côte d'Ivoire & Egypt, Arab Rep. & Cameroon \\
Congo, Rep. & Guatemala & Honduras & El Salvador \\
Ghana & Kenya & Kyrgyz Republic & India \\
Indonesia & Mauritania & Moldova & Lao PDR \\
Lesotho & Philippines & Senegal & Morocco \\
Pakistan & Swaziland & Syrian Arab Republic & Sri Lanka \\
Sudan & Vietnam & Yemen, Rep. & Tajikistan \\
Ukraine & & & Zambia \\
\hline Low income (18) & Burundi & Cambodia & Central African Republic \\
Benin & Liberia & Malawi & Mali \\
Gambia, The & Nepal & Niger & Rwanda \\
Mozambique & Tanzania & Togo & Uganda \\
Sierra Leone & Zimbabwe & & \\
Congo, Dem. Rep. & &
\end{tabular}

\section{References}

1. Anbarci, N.; Escaleras, M.; Register, C.A. Earthquake fatalities: The interaction of nature and political economy. J. Public Econ. 2005, 89, 1907-1933. [CrossRef]

2. Kahn, M. The death toll from natural disasters: The role of income, geography, and institutions. Rev. Econ. Stat. 2005, 87, 271-284. [CrossRef]

3. Toya, H.; Skidmore, M. Economic development and the effects of natural disasters. Econ. Lett. 2007, 94, 20-25. [CrossRef]

4. Kellenberg, D.K.; Mobarak, A.M. Does rising income increase or decrease damage risk from natural disasters? J. Urban Econ. 2008, 63, 788-802. [CrossRef]

5. Toya, H.; Skidmore, M. Information/communication technology and natural disaster vulnerability. Econ. Lett. 2015, 137, 143-145. [CrossRef]

6. Tadesse, G.; Bahiigwa, G. Mobile phones and farmers' marketing decisions in Ethiopia. World Dev. 2015, 68, 296-307. [CrossRef]

7. Muto, M.; Yamano, T. The impact of mobile phone coverage expansion on market participation: Panel data evidence from Uganda. World Dev. 2009, 37, 1887-1896. [CrossRef]

8. Donner, J.; Tellez, C.A. Mobile banking and economic development: Linking adoption, impact and use. Asian J. Commun. 2008, 18, 318-332. [CrossRef]

9. Kiiza, B.; Pederson, G. ICT-based market information and adoption of agricultural seed technologies: Insights from Uganda. Telecommun. Policy 2012, 36, 253-259. [CrossRef]

10. Donner, J. Research approaches to mobile use in the developing world: A review of the literature. Inf. Soc. Int. J. 2006, 24, 140-159. [CrossRef]

11. Samarajiva, R.; Waidyanatha, N. Two complementary mobile technologies for disaster warning. Info 2009, 11, 58-65. [CrossRef]

12. Jagtman, H.M. Design for safety: A new service for alarming and informing the population in case of emergency. Infranomics Sustain. Eng. Des. Gov. 2014, 24, 103-124.

13. Wang, Y.; Wang, T.; Ye, X.; Zhu, J.; Lee, J. Using social media for emergency response and urban sustainability: A case study of the 2012 Beijing rainstorm. Sustainability 2016, 8, 25. [CrossRef]

14. Khalafzai, A.K.; Nirupama, N. Building resilient communities through empowering women with information and communication technologies: A Pakistan case study. Sustainability 2008, 3, 82-96. [CrossRef]

15. Vieweg, S.; Hughes, A.L.; Starbird, K.; Palen, L. Microblogging during two Natural hazards events: What Twitter may contribute to situational awareness. Crisis Inform. 2010, 2, 1079-1088.

16. Collins, M.; Kapucu, N. Early warning systems and disaster preparedness and response in local government. Disaster Prev. Manag. Int. J. 2008, 17, 587-600. [CrossRef] 
17. Quarantelli, E.L. Problematical aspects of the information/communication revolution for disaster planning and research: Ten non-technical issues and questions. Disaster Prev. Manag. Int. J. 1997, 6, 94-106. [CrossRef]

18. Wildavsky, A. Searching for Safety; Transaction Books: New Brunswick, NJ, USA, 1988.

19. Horwich, G. Economic lessons from the Kobe earthquake. Econ. Dev. Cult. Chang. 2000, 48, 521-542. [CrossRef]

20. Tol, R.; Leek, F. Economic analysis of natural disasters. In Climate Change and Risk; Downing, T., Olsthoorn, A.R., Tol, R., Eds.; Routledge: London, UK, 1999.

21. Burton, I.; Kates, R.W.; White, G.F. The Environment as Hazard, 2nd ed.; Guilford Press: New York, NY, USA, 1993.

22. Albala-Bertrand, J.M. The Political Economy of Large Natural Disasters; Oxford University Press: New York, NY, USA, 1993.

23. Alexander, D. Natural Disasters; Chapman and Hall: New York, NY, USA, 1993.

24. Briguglio, L. Small island developing states and their economic vulnerabilities. World Dev. 1995, 23, 1615-1632. [CrossRef]

25. Adger, N. Social vulnerability to climate change and extremes in coastal Vietnam. World Dev. 1999, 27, 249-269. [CrossRef]

26. Pelling, M.; Uitto, J. Small island developing states: Natural disaster vulnerability and global change. Glob. Environ. Chang. Part B Environ. Hazards 2001, 3, 49-62. [CrossRef]

27. EM-DAT. The Emergency Events Database-Université Catholique de Louvain (UCL)-CRED, D. Guha-Sapir. Available online: www.emdat.be (accessed on 20 April 2015).

28. Feenstra, R.C.; Inklaar, R.; Timmer, M.P. The next generation of the Penn World Table. Am. Econ. Rev. 2015, 105, 3150-3182. [CrossRef]

29. The World Bank. World Development Indicators. Available online: http://data.worldbank.org/indicator (accessed on 20 April 2015).

30. CRED. The Internet Disaster Database. Available online: http://www.emdat.be/guidelines (accessed on 20 May 2016).

31. Felbermayr, G.; Gröschl, J. Naturally negative: The growth effects of natural disasters. J. Dev. Econ. 2014, 111, 92-106. [CrossRef]

32. Bertrand, M.; Duflo, E.; Mullainathan, S. How much should we trust differences-in-differences estimates? Quart. J. Econ. 2004, 119, 249-275. [CrossRef]

33. Kezdi, G. Robust standard-error estimations in fixed-effect panel models. Hungarian Stat. Rev. 2004, 9, 95-116. [CrossRef]

34. Anselin, L.; Bera, A. Spatial dependence in linear regression models with an introduction to spatial econometrics. In Handbook of Applied Economic Statistics; Ullah, A., Giles, D., Eds.; Marcel Dekker: New York, NY, USA, 1998.

35. Kondo, K. SPGEN: Stata Module to Generate Spatially Lagged Variables. 2015. Available online: http: / / econpapers.repec.org/software/bocbocode/S458105.htm (accessed on 15 August 2017).

36. Penn World Table. American Economic Review. Available online: http://www.rug.nl/ggdc/productivity / pwt/ (accessed on 17 April 2016).

(C) 2018 by the authors. Licensee MDPI, Basel, Switzerland. This article is an open access article distributed under the terms and conditions of the Creative Commons Attribution (CC BY) license (http:/ / creativecommons.org/licenses/by/4.0/). 